\title{
IMPLEMENTASI KEBIJAKAN NASIONAL KUNJUNGAN MASA NIFAS PADA PRAKTIK MANDIRI BIDAN HJ. NORHIDAYATI BANJARMASIN
}

\author{
Yerika Elok Novembriany \\ Akademi Kebidanan Bunga Kalimantan, Banjarmasin, Kalimantan Selatan, \\ Indonesia, 70123 \\ Email: yerika.dicky@gmail.com
}

\begin{abstract}
The process of pregnancy and childbirth is a physiological experienced by almost all women, as well as the postpartum period. The postpartum national program is one of the government's efforts in the context of early detection of infections and complications that may occur during the puerperium by visiting four times during the puerperium period. The purpose of this study was to determine the implementation of the national policy for postpartum visits in the independent practice of midwives (PMB) Hj. Norhidayati. This Research was a descriptive analytic, using a cross sectional design. The population in this study were postpartum mothers who gave birth at PMB Hj. Norhidayati. 53 people research sample collected using accidental sampling technique. The research was conducted at PMB Hj. Norhidayati in January -May 2021. The results showed that the midwife made the first postnatal visit (6-8 hours PP) and the second postpartum visit (6 days PP) to all mothers who gave birth at PMB Hj. Norhidayati. The third postpartum visit (2 weeks PP) was carried out for most patients, namely as many as 48 patients (90.57\%), while the IV postpartum visit (6 weeks PP) was carried out to 41 patients $(77.36 \%)$ who gave birth in PMB Hj. Norhidayati. This study concluded that midwife has implemented the national policy of postpartum visits well. However, there are several obstacles, including time constraints and difficult terrain to achieve the program.
\end{abstract}

Keywords: Midwife, National policy, Postpartum visit

\begin{abstract}
Abstrak
Proses kehamilan dan persalinan adalah proses yang fisiologis yang dialami oleh hampir semua wanita, begitu pula masa nifas. Program nasional masa nifas merupakan salah satu upaya pemerintah untuk melakukan deteksi dini infeksi dan komplikasi yang mungkin terjadi dengan cara melakukan kunjungan sebanyak empat kali selama periode masa nifas. Tujuan penelitian ini adalah untuk mengetahui implementasi kebijakan nasional kunjungan nifas di praktik mandiri bidan (PMB) $\mathrm{Hj}$. Norhidayati Metode yang digunakan yaitu deskriptif analitik, menggunakan pendekatan cross sectional. Populasi dalam penelitian ini adalah ibu nifas yang bersalin di PMB Hj. Norhidayati, Sampel penelitian 53 orang, Teknik pengambilan sampel acsidental. Penelitian dilakukan di PMB Hj. Norhidayati pada bulan Januari -Mei 2021. Hasil penelitian menunjukkan Bidan melakukan kunjungan nifas I (6-8 jam PP) dan kunjungan nifas ke II (6 hari PP) kepada semua ibu yang bersalin di PMB Hj. Norhidayati. Kunjungan nifas ke III (2 minggu PP) dilakukan kepada sebagian besar pasien yaitu yaitu sebanyak 48 pasien $(90,57 \%)$, sedangkan kunjungan nifas ke IV (6 minggu PP) dilakukan kepada 41 orang pasien $(77,36 \%)$ yang bersalin di PMB Hj. Norhidayati. Penelitian ini menyimpulkan bahwa Bidan telah mengimplementasikan kebijakan nasional kunjungan masa nifas dengan baik. Namun, terdapat beberapa kendala antara lain keterbatasan waktu dan medan yang sulit ditempuh.
\end{abstract}

Kata kunci: Bidan, Kebijakan nasional, Kunjungan nifas 


\section{Pendahuluan}

Proses kehamilan dan persalinan adalah proses yang fisiologis dialami oleh hampir semua wanita, begitu pula masa nifas. Masa Nifas adalah masa yang dimulai dari plasenta lahir sampai enam minggu post-partum (alat-alat reproduksi normal kembali seperti sebelum hamil) (Saifudin, 2002). Asuhan masa nifas diperlukan karena merupakan masa kritis baik untuk ibu maupun bayinya. Lima puluh persen kematian ibu terjadi pada masa nifas dan terjadi 24 jam pertama. Campbell (2010) menambahkan bahwa masa post-partum adalah masa yang sangat penting sehingga perlu dukungan dan motivasi serta pelayanan kesehatan yang terintegrasi dari tenaga kesehatan.

Dalam masa nifas ini, tidak sedikit ibu yang mengalami problem kesehatan seperti nyeri, bengkak pada kaki, ketidakmampuan menyusui dan nutrisi. Budaya dan mitos yang kadang kurang menguntungkan kesehatan ibu di masa nifas masih menjadi masalah.

Program nasional masa nifas merupakan salah satu upaya pemerintah untuk melakukan deteksi dini infeksi dan komplikasi yang mungkin terjadi pada masa nifas, dengan cara melakukan kunjungan sebanyak empat kali selama periode masa nifas. Bidan mempunyai peran yang sangat penting dalam masa ini melalui pendidikan kesehatan, monitoring, dan deteksi dini bahaya nifas.

Kunjungan selama nifas sering dianggap tidak penting oleh tenaga kesehatan karena sudah merasa baik dan selanjutnya berjalan dengan lancar. Konsep early ambulation dalam masa post-partum merupakan hal yang perlu diperhatikan karena terjadi perubahan hormonal. Pada masa ini, ibu membutuhkan petunjuk dan nasihat dari bidan sehingga proses adaptasi setelah melahirkan berlangsung dengan baik.

Bidan memegang peranan penting dalam upaya pemerintah untuk meningkatkan kesehatan dan pengertian masyarakat melalui konsep promotif, preventif, kuratif dan rehabilitatif. Dalam standar pelayanan kebidanan, bidan memberikan pelayanan bagi ibu pada masa nifas melalui kunjungan rumah pada hari ketiga, minggu kedua dan minggu keenam setelah persalinan untuk membantu proses pemulihan ibu dan bayi melalui penanganan tali pusat yang benar, penemuan dini, penanganan atau rujukan komplikasi yang mungkin terjadi pada masa nifas, serta memberikan penjelasan tentang kesehatan secara umum, personal hygiene, nutrisi, perawatan bayi baru lahir, pemberian ASI, imunisasi dan keluaga berencana.
Tenaga kesehatan selalu melakukan pemantauan karena pelaksanaan yang kurang maksimal, yang dapat menyebabkan ibu mengalami berbagai masalah bahkan dapat berlanjut pada komplikasi masa nifas, seperti sepsis puerperalis. Infeksi merupakan penyebab kematian terbanyak nomor dua setelah perdarahan, sehingga sangat tepat jika para tenaga kesehatan memberikan perhatian yang tinggi pada masa ini.

Permasalahan pada ibu akan berimbas juga kepada kesejahteraan bayi yang dilahirkan karena bayi tersebut tidak akan mendapatkan perawatan maksimal dari ibunya. Lagi, angka morbiditas dan mortalitas bayi akan semakin meningkat.

Latar belakang permasalahan yang telah diuraikan di atas menjadi dasar untuk menggali implementasi kebijakan nasional kunjungan masa nifas pada praktik mandiri bidan $\mathrm{Hj}$. Norhidayati, sehingga penelitian ini dapat memberikan manfaat bagi tempat penelitian dan masyarakat pada umumnya.

\section{METODE PENELITIAN}

Penelitian ini bersifat deskriptif analitik, menggunakan pendekatan cross sectional. Data yang gunakan adalah data primer dan data sekunder. Pengumpulan data ini dilakukan dengan cara melakukan wawancara kepada ibu nifas untuk mendapatkan gambaran tentang pelaksanaan kebijakan program nasional kunjungan masa nifas di PMB Hj. Norhidayati Banjarmasin. Data sekunder diperoleh melalui register ibu nifas yang ada di PMB Hj. Norhidayati untuk mengetahui frekuensi kunjungan masa nifas. Instrument yang digunakan berupa panduan wawancara dan lembar observasi sesuai dengan Standar pelayanan masa nifas.

Analisis data dilakukan dengan teknik penjelasan (explanation building). Analisis data dilakukan dengan menganalisis transkrip wawancara untuk mendapatkan gambaran tentang pelaksanaan kebijakan program nasional kunjungan masa nifas di PMB $\mathrm{Hj}$. Norhidayati pada bidan yang berpraktik. Hasil yang didapat dipertajam kembali dengan temuan-temuan ketika dilakukan observasi ke tempat penelitian. Setelah data terkumpul, datadata berupa angka kemudian dianalisis menggunakan statistik uji statistik Chi Kuadrat dengan nilai kemaknaan $p<0,05$. Data selanjutnya diolah dengan menggunakan komputerisasi.

Pemilihan sampel dalam penelitian ini dilakukan dengan menggunakan teknik nonprobability sampling, teknik sampling yang dipilih yaitu 
aksidental. Sampel yaitu ibu nifas yang bersalin di PMB Hj. Norhidayati pada bulan Januari -Mei 2021 sebanyak 53 orang. Pemilihan tempat penelitian dilakukan secara randomisasi di PMB Hj. Norhidayati.

\section{HASIL PENELITIAN}

Data hasil penelitian disajikan pada tabel berikut:

\section{Tabel 1. Distribusi Responden berdasarkan Umur}

\begin{tabular}{ccc}
\hline Umur & Jumlah & \% \\
\hline$<20$ tahun & 0 & 0 \\
$20-35$ tahun & 49 & 92,45 \\
$>35$ tahun & 4 & 7,55 \\
Jumlah & 53 & 100 \\
\hline
\end{tabular}

(Sumber : Data sekunder, 2021)

Tabel 1 di atas menunjukkan bahwa sebagian besar responden berusia 20-35 tahun sebanyak 49 orang $(92,45 \%)$.

Tabel 2. Distribusi Responden berdasarkan Paritas

\begin{tabular}{lcc}
\hline \multicolumn{1}{c}{ Paritas } & Jumlah & \% \\
\hline Primipara & 7 & 13,21 \\
Multipara & 41 & 77,36 \\
Grandemultipara & 5 & 9,43 \\
Jumlah & 53 & 100 \\
\hline
\end{tabular}

Tabel 2 di atas menunjukkan bahwa sebagian besar responden dengan kategori paritas multipara adalah sebanyak 41 orang $(77,36 \%)$.

Tabel 3. Distribusi Frekuensi Implementasi Kebijakan Kunjungan Masa Nifas di PMB Hj. Norhidayati.

\begin{tabular}{|c|c|c|c|}
\hline No & Kunjungan Nifas & $\mathbf{f}$ & $\%$ \\
\hline \multirow[t]{3}{*}{1} & 6-8 Jam PP & & \\
\hline & Dilakukan & 53 & 100 \\
\hline & Tidak Dilakukan & & 0 \\
\hline \multirow[t]{3}{*}{2} & 6 hari PP & & \\
\hline & Dilakukan & 53 & 100 \\
\hline & Tidak Dilakukan & & 0 \\
\hline \multirow[t]{3}{*}{3} & 2 minggu PP & & \\
\hline & Dilakukan & 48 & 90,57 \\
\hline & Tidak Dilakukan & & 9,43 \\
\hline \multirow[t]{3}{*}{4} & 6 minggu PP & & \\
\hline & Dilakukan & 41 & 77,36 \\
\hline & Tidak Dilakukan & 12 & 22,64 \\
\hline
\end{tabular}

Tabel 3 menunjukkan bahwa Bidan melakukan kunjungan nifas I (6-8 jam PP) dan kunjungan nifas ke II (6 hari PP) kepada semua ibu yang bersalin di PMB Hj. Norhidayati.

Kunjungan nifas ke III (2 minggu PP) dilakukan kepada sebagian besar pasien yaitu yaitu sebanyak 48 pasien $(90,57 \%)$, sedangkan kunjungan nifas ke IV (6 minggu PP) dilakukan kepada 41 orang pasien $(77,36 \%)$ yang bersalin di PMB $\mathrm{Hj}$. Norhidayati.

\section{PEMBAHASAN}

Masa nifas adalah masa sesudah persalinan dan kelahiran bayi, plasenta, serta selaput yang diperlukan untuk memulihkan kembali organ kandungan seperti sebelum hamil dengan waktu kurang lebih enam minggu, sehingga pada masa nifas terjadi perubahan-perubahan pada sistem dalam tubuh (Saleha, 2009). Selain perubahan pada sistem dalam tubuh, terjadi juga perlukaan pada jalan lahir. Perlukaan karena persalinan merupakan tempat masuknya kuman ke dalam tubuh dan dapat menimbulkan resiko terjadinya infeksi pada masa nifas, sehingga membutuhkan pengawasan untuk deteksi dini resiko yang terjadi pada masa nifas (Prawirohardjo, 2007).

Penatalaksanaan asuhan yang diberikan pada pasien mulai dari saat setelah lahirnya bayi sampai dengan kembalinya tubuh dalam keadaan seperti sebelum hamil atau mendekati keadaan sebelum hamil sehingga asuhan masa nifas yang diberikan bidan seharusnya sampai enam minggu setelah melahirkan. Asuhan masa nifas diperlukan karena masa nifas merupakan masa kritis baik untuk ibu maupun bayinya sehingga harus mendapatkan pengawasan terus menerus sampai 40 hari setelah melahirkan.

Kunjungan pada ibu nifas sangat penting untuk dilakukan karena dengan melakukan kunjungan sampai 40 hari masa ibu nifas, bidan dapat memantau perubahan-perubahan yang terjadi pada ibu nifas seperti proses involusio, memantau banyaknya perdarahan dan memantau proses laktasi.

PMB Hj. Norhidayati telah melakukan kegiatan/asuhan yang seharusnya dilakukan pada kunjungan 6-8 jam sampai dengan 6 minggu postpartum. Bidan melakukan pemantauan kontraksi uterus, melakukan konseling cara mencegah perdarahan, memastikan ibu mendapatkan cukup makanan dan cairan, melakukan konseling tentang bonding attachment, melakukan konseling tentang pencegahan hipotermia pada bayi dan konseling 
pemberian ASI awal, konseling KB, dan pemberian imunisasi pada bayi. Tujuan asuhan masa nifas adalah menjaga kesehatan ibu dan bayinya baik fisik maupun psikologis, melaksanakan skrining yang komprehensif, mendeteksi masalah, mengobati atau merujuk bila terjadi komplikasi pada ibu maupun bayinya, memberikan pendidikan kesehatan tentang perawatan kesehatan diri, nutrisi, menyusui, pemberian imunisasi kepada bayinya dan perawatan bayi sehat, dan memberikan pelayanan KB (Keluarga Berencana) (Saleha,2009).

Perawatan bayi adalah suatu tindakan merawat dan memelihara kesehatan bayi dalam bidang preventif dan kuratif. Bayi baru lahir harus mampu beradaptasi dengan lingkungan yang baru karena setelah plasentanya dipotong maka tidak ada lagi asupan makanan dari ibu. Kondisi bayi baru lahir masih rentan terhadap penyakit, karena itulah bayi memerlukan perawatan yang insentif (Deslidel dkk, 2011).

Pada masa nifas, ibu memerlukan tambahan nutrisi tiga kali lipat dari kondisi biasanya untuk pemulihan tenaga atau aktivitas ibu, metabolisme, cadangan dalam tubuh, penyembuhan luka jalan lahir, serta untuk memenuhi kebutuhan bayi berupa produksi ASI. Diet yang diberikan harus bermutu tinggi dengan cukup kalori, cukup protein, cairan, serta banyak buah-buahan karena ibu nifas mengalami hemokonsentrasi (Wiknjosastro, 2007). Banyaknya anggapan atau mitos yang ada di masyarakat tentang pantang makanan tertentu pada masa nifas mengharuskan bidan memberikan konseling tentang nutrisi pada ibu segera setelah ibu melahirkan.

Penerapan kebijakan program nasional masa nifas tidak hanya melakukan kunjungan ke rumah tetapi termasuk pemberian asuhan kebidanan pada pasien selama masa nifas. Hasil wawancara yang dilakukan dengan responden bidan menunjukkan hambatan yang dialami tidak hanya dari bidan saja tetapi juga berasal dari pasien. Hambatan tersebut umumnya berupa adanya mitos-mitos yang sampai saat ini masih dipercaya oleh masyarakat, sehingga pasien lebih percaya dengan masyarakat dan keluarga dibandingkan dengan bidan.

Hasil wawancara juga menunjukkan bahwa terdapat hambatan-hambatan lain dalam menerapkan kebijakan program masa nifas, seperti adanya keterbatasan waktu dan tenaga. Jumlah Bidan yang bertugas, Bidan jaga tidak mencukupi sehingga tidak mempunyai waktu untuk melakukan kunjungan ke rumah pasien. Beberapa bidan membuat suatu kebijakan yang mengharuskan pasien untuk melakukan kunjungan ulang ke tempat pelayanan, sehingga bidan tidak harus melakukan kunjungan ke rumah pasien.

Selanjutnya Responden mengatakan bahwa hambatan dari bidan terutama karena tidak adanya waktu untuk melakukan kunjungan ke rumah pasien. Bidan beralasan tenaga yang ada tidak begitu banyak. Medan yang sulit untuk dapat mencapai rumah bahwa jika harus mengunjungi semua pasien yang melahirkan sampai kunjungan ke-4, tidak ada waktu untuk pasien-pasien yang lain serta tidak adanya kebijakan dari klinik juga membuat bidan tidak melakukan kunjungan ke rumah pasien.

\section{KESIMPULAN}

Hasil penelitian dan pembahasan menyimpulkan bahwa Bidan melakukan kunjungan nifas I (6-8 jam PP) dan kunjungan nifas ke II (6 hari PP) kepada semua ibu yang bersalin di PMB Hj. Norhidayati. Kunjungan nifas ke III (2 minggu PP) dilakukan kepada Sebagian besar pasien yaitu yaitu sebanyak 48 pasien $(90,57 \%)$, sedangkan kunjungan nifas ke IV (6 minggu PP) dilakukan kepada 41 orang pasien $(77,36 \%)$ yang bersalin di PMB $\mathrm{Hj}$. Norhidayati. Beberapa responden bidan mengatakan bahwa hambatan yang dialami untuk penerapan kunjungan masa nifas adalah tidak adanya waktu untuk melakukan kunjungan, tempat tinggal yang jauh dari tempat pelayanan (PMB), tidak adanya jadwal dan kebijakan dari PMB untuk pelaksanaan home care atau kunjungan rumah.

Setiap bidan praktik swasta sebaiknya mengatur jadwal untuk melakukan kun- jungan masa nifas sampai enam minggu postpartum dan wajib melakukan seluruh asuhan yang harus diberikan pada masa nifas untuk deteksi dini infeksi dan komplikasi masa nifas. Institusi pendidikan hendaknya mem- berikan pengajaran yang menekankan pen- tingnya asuhan pada masa nifas mulai dari 6-8 jam sampai dengan enam minggu setelah melahirkan.

\section{ACKNOWLEDGEMENT}

Ucapan terima kasih kepada seluruh pihak yang telah membantu kelancaran proses penelitian sampai akhir, terutama manajemen BPS $\mathrm{Hj}$. Norhidayati dan Akademi Kebidanan Bunga Kalimantan. 


\section{Daftar Rujukan}

Bahiyatun. 2009. Asuhan Kebidanan Nifas Normal. EGC: Jakarta.

Baumali, A. 2009. Pemenuhan Zat Gizi Ibu Nifas dan Budaya Se'l pada Masyarakat Suku Timor Dawan di Kecamatan Molo Selatan Kabupaten Timor Tengah Selatan. Tesis tidak diterbitkan. Yogyakarta: Prodi Ilmu Kesehatan Masyarakat Universitas Gajah Mada.

Blaxter, L. Hughter, C. \& Thigt, M. 2001. How to ReSearch; Seluk Beluk Melakukan Riset. Edisi Kedua. PT. Indeks Kelompok Gramedia: Jakarta.

Campbell, K. 2010. PostPartum Doulas: Motivation and Perceptions of Practice, (online), (http//www. elsevier.com/midw), diakses 1 April 2021.

Mochtar, R. 2002. Sinopsis Obstetri. EGC: Jakarta.

Padminingrum, D., Widiyanti, E. 2005. DasarDasar Komunikasi; (Modul Pembelajaran). UNS: Surakarta. Prawirohardjo, S. 2007. Ilmu Kebidanan. FKUI: Jakarta.

Saifudin, A.B. 2002. Buku Panduan Praktis Pelayanan Kesehatan Maternal dan Neonatal. Penerbit Yayasan Bina Pustaka Sarwono Prawirohardjo: Jakarta.

Saleha. 2009. Asuhan Kebidanan Pada Masa Nifas. Salemba Medika: Jakarta.

Wiknjosastro, H. 2007. Ilmu Kebidanan. Penerbit Yayasan Bina Pustaka

Sarwono Prawirohardjo: Jakarta. Yin, R.K. 2006. Studi Kasus Desain dan Metode. Divisi Buku Perguruan Tinggi. PTRaja Grafindo Persada: Jakarta. 
P- ISSN: 2527-5798, E-ISSN: 2580-7633

Jurnal Keperawatan Suaka Insan (JKSI) Vol. 6, No. 2, Desember 2021 